\title{
Development and quality analysis of a learning media electrical motor installation on the Android platform, for vocational students
}

\author{
B. N. Setyanto \& H. Jati \\ Yogyakarta State University, Indonesia
}

ABSTRACT: The purpose of this study is to design a learning media electrical motor installation (EMI) application with quality standardization. The research was conducted with the research and development approach. The product discussed is two applications that can be used on smartphones on the Android platform. The two applications have the same content but different interface designs, so that comparisons could be made to obtain quality products. Data was collected through a questionnaire, offline tests (direct testing), and online tests (cloud testing). Quality analysis was carried out with reference to ISO 25010. This study shows that the the first application (IML-WA) is higher quality than the second application (IML-BBM): an analysis of functional suitability and compatibility aspects scored the applications as equal in quality, while the usability and performance efficiency aspects show that IMLWA received a higher mean rank score than IML-BBM.

\section{INTRODUCTION}

\subsection{Research background}

Vocational High School is one of the highest secondary education levels for vocational education in Indonesia. According to the Law of Republic Indonesia No. 20 in 2003 Article 15 , vocational schools aim to prepare students specifically to work in certain fields. Meanwhile, a decree from the former Minister of Education and Culture Republic Indonesia number 179342/ MPK/KR/2014 stated that a teacher must develop methods of learning with creativity, dare to innovate and be able to carry out a learning process that is fun for students (Baswedan, 2014).

In the era of the education revolution 4.0, there are demands on teachers to develop technology-based learning media that meet quality standards, as the application of technology in education can be exciting opportunities that can potentially transform society for the better (Xing, 2017). Lecturers and students should apply education 4.0 principles in order to help the students to compete in the era of 4.0 (Candradewi, 2018).

Winarto and Winih Wicaksono, as the teachers responsible for electric motor installation (EMI) and the masters for the Expertise Program of the Electric Power Installation Engineering (TIPTL) at the Vocational High School in Yogyakarta described the problem as follows. (1) EMI are categorized as difficult lessons. (2) EMI requires the right media innovation for the learning process. (3) Around $80 \%$ of students have Android platform smartphones. (4) There is a need to create an Android learning media platform that can display short theories, and installation steps in the form of simulation 
images, exercises, and theoretical questions. (5) The learning process carried out is still conventional using the EMI practice module. (6) Can we make a learning media is an interesting and high quality? (7) Teaching materials of electronic school books (BSE) particularly in vocational high school.

International Data Corporation (IDC) stated that, in Q1 2017, worldwide, smartphone use had increased to 1.46 billion devices, and this was dominated by the Android platform (85.0\%), iOS (14.7\%), Windows Phone (0.1\%), and (0.1\%). Indonesian internet service provider association (APJII) showed that, in 2017, in Indonesia 143.26 million people were internet users: with a $50.08 \%$ owned smartphone or tablet devices, of which $70.96 \%$ was owned by urban dwellers, and of this student users age 13-18 years accounted for $75.70 \%$.

Based on the Global State StatCounter for the period July 2017 to July 2018, in Indonesia the smartphone market was as follows: Android system $87.79 \%$, IOs $5.65 \%$, and Blackberry $0.37 \%$. Android-based communication media can produce changes in scientific attitudes in the learning process and increase the completeness of learning outcomes (Juwarti, 2015). Similarly, Prasetyo (2015) stated that Android-based media can improve student motivation and cognitive learning outcomes. Sumari (2015) stated that Android-based m-learning learning media can improve critical thinking skills and students' learning independence.

It was noted by Vaugan (2011) that the combination of text, art, sound, animation, and video sent to users by computers or other manipulated electronic or digital means is considered as multimedia. UNESCO (2014) adds that m-learning as mobile learning involves the use of mobile technology either alone or in combination with information and other communication technologies, and thus allows learning anytime and anywhere.

Branch (2009) explained that the model Analyze, Design, Develop, Implement, and Evaluate (ADDIE) is a learning planning design model that emphasizes studentcentered, innovative, authentic, and inspiring. In addition, the ADDIE model can be used to develop educational products and learning resources. In connection, Sumari (2015) found that the research process for the development of Android-based learning media can use the ADDIE model. Similarly, Prasetyo (2015) also stated that research on the development of Android-based learning media can use the ADDIE development model.

Software testing is a process of executing a software product on input data and output data analysis (Mili, 2015). Suman (2014) explained that the main purpose of software engineering is of high quality and sustainable for use. Furthermore, Thomas (2017) stated that in the design comparison of a product, consumers are asked to use two products and then determine which is better. Several years before, Panovski (2008) suggested that in the process of analyzing a software product there are significant differences between application software products and software development products.

Software quality standards, including ISO 9126, ISO 25010, McCall Model, DROMEY, and FURP, are international standard models used in measuring software quality. Hidayati, Sarwosri, and Ririd (2009) described ISO 9126 as a standard used as a quality model in developing learning media applications. However, in 2012 ISO 9126 evolved to ISO 25010, so the quality test was better when using ISO 25010 (ISO/IEC, 2011).

According to Wagner (2013), ISO 25010 establishes eight aspects of product quality standards: functional suitability, reliability, performance efficiency, usability, maintainability, security, compatibility, and portability. David (2011) proposed that the quality analysis used in software product research with the Android platform can use four of these eight aspects: functional suitability, compatibility, usability, and performance.

Therefore, a summary of the above description is that the Indonesian education 
minister made a statement concerning developments in the evolution of education 4.0, which might be associated with the increased use of Android smartphones, and the desire of subject teachers to have quality learning media to improve the quality of learning. So, research needs to be done to produce quality media. In developing a product, a comparison is needed to get a better product, so that at least two products have been developed.

\subsection{Research focus}

Based on this problem, this study focuses on obtaining quality learning media products based on ISO 25010 standards, by comparing the two products in term of quality, analyzed on aspects of functional suitability, compatibility, usability, and performance efficiency.

\section{RESEARCH METHODS}

This research used the research and Development (R\&D) approach with the ADDIE learning design development model. The purpose of this development research is to produce a quality product in reference to SO 25010. The process of developing the learning media was done by using the world's most popular messenger application interface,s Whatsapp Messenger and BBM Messenger. On May 15, 2018, the Whatsapp Messenger application ranked first with score of 4.4 and BBM Messenger ranked second with score of 4.3 (Google Play Store, 2018). Two user interface models were used in order to determine the best choice of applications for students. The development followed the provisions of the design material concept by Google.

The steps taken in developing this learning media are described below.

\subsection{Analyze}

A pre-survey was conducted to establish the requirements for learning media in schools. The results were: (1) identifying the subjects that need learning media; (2) obtaining curriculum information used; (3) obtaining and identifying subject matter; (4) obtaining media information data used; (5) determining the application for development that is suitable for the media.

\subsection{Design}

The Android platform learning media IML was designed into two applications with the same learning matter, but with differences in terms of layout. Layout A was designed to resemble the Whatsapp Messenger application and was named IML-WA, and layout $B$ was designed to resemble BBM Messenger and was named IML-BBM. These design stages included (1) a design a use case diagram, (2) design a flowchart, and (3) design the user interface.

\subsection{Develop}

The development stage was conducted by preparing the content of the learning material and determining the media developed. The media developed in this study is an application media platform for Android, that designs processes for an Adobe Flash CS6 application using adobe Integrated Runtime(AIR) version 30 (Brossier 2011). The product was tested to find out the validity based on judgments from experts on learning the material, the media, and the functional suitability. The process for the 
validity of the learning media was tested using the SPSS application (George \&Mallery, 2003).

\subsection{Implement}

The implementation phase was conducted with cloud testing on compatibility and performance efficiency aspects. After cloud testing was completed and there were no more any revisions, the final stage of testing was conducted to find out the usability aspects of the two learning media for Vocational High School students in Indonesia.

\subsection{Evaluate}

After the implementation phase, the final development phase was the quality evaluation of the two media, developed with ISO 25010 analysis procedures on aspects of functional suitability, compatibility, performance efficiency, and usability. Usability testing was performed with a minimum of 20 users for better results of the study (Nielsen, 2012). After obtaining the expected results, the significant difference test was carried out between the two applications to find out which was higher quality (Niknejad, 2011).

\section{RESULTS AND DISCUSSION}

The final products of the design IML-WA and IML-BBM learning media applications are shown in Figure 1.

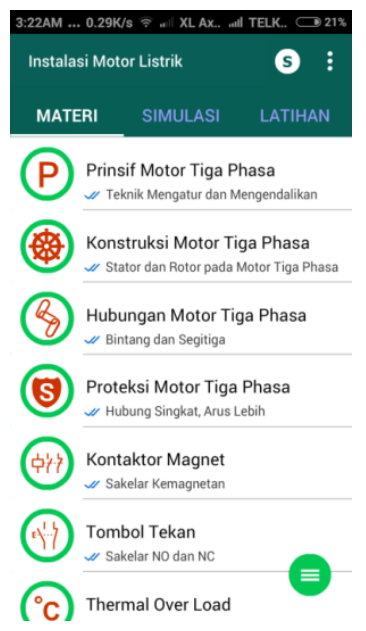

(a) IML-WA

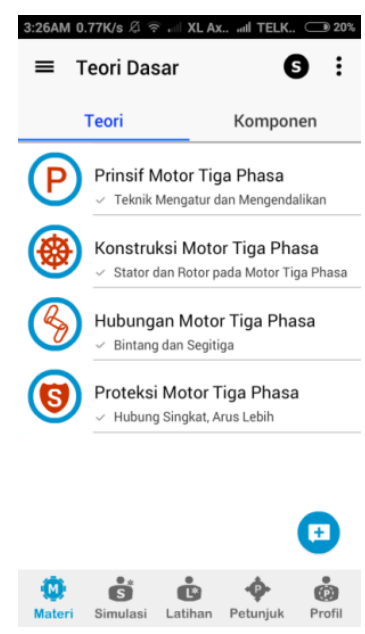

(b) IML-BBM

Figure 1. Main menu IML-WA and IML-BBM

The validity of the two applications performed by media experts was "very feasible", with a mean score of 4.49 . In addition, $100 \%$ of subject matter experts scored the validity as "valid".

\subsection{Functional testing}

Functional suitability testing was performed by two Android developers from PT. Putra Multi Cipta Teknikindo (PMCT) showed that the two applications functioned $100 \%$ successfully. Thus both applications functioned properly and satisfied the appropriate 
material criteria.

\subsection{Compatibility testing}

The result of compatibility online testing on Amazon apps \& Games shows more than 208 devices supported. Compatibility of online testing on www.portal.kobiton.com and www.cloud.bitbar.com (Bitbar, 2018) is shown in Table 1. Direct testing is shown in Table 2.

Table 1. Compatibility of online testing

\begin{tabular}{|c|c|c|c|}
\hline No & Smartphone & Version & Result \\
\hline 1 & Acer Iconia 8 & 4.4 .2 & Running \\
\hline 2 & Asus Fonepad & 4.1 .0 & Running \\
\hline 3 & $\begin{array}{l}\text { Asus Google Nexus } \\
7\end{array}$ & 4.1 .2 & Running \\
\hline $\begin{array}{l}4 \\
5 \\
6\end{array}$ & $\begin{array}{l}\text { Lenovo S820 } \\
\text { Samsung J7 Prime } \\
\text { Samsung J7 Pro }\end{array}$ & $\begin{array}{l}4.2 .0 \\
6.0 .0 \\
7.0 .0\end{array}$ & $\begin{array}{l}\text { Running } \\
\text { Running } \\
\text { Running }\end{array}$ \\
\hline
\end{tabular}

Table 2. Compatibility direct testing

\begin{tabular}{clcc}
\hline No & Smartphone & Version & Result \\
\hline 1 & Key touch S100 & 4.1 .2 & Running \\
2 & XiaomiRedmi 2 & 4.4 .4 & Running \\
3 & SmartfrenAndromaxU & 4.0 .4 & Running \\
4 & Oppo A37f & 5.1 .1 & Running \\
5 & Asus Z00 & 5.0 .2 & Running \\
6 & Xiaomiredmi note4x & 6.0 .0 & Running \\
7 & Advan S5E 4GS & 7.0 .0 & Running \\
\hline
\end{tabular}

The compatibility testing shows that the two applications were found to be $100 \%$ compatible and supported on any smartphones. So there are no obstacles to implementation.

\subsection{Usability testing}

Usability testing with 76 students shows that the IML-WA application has a reliable Cronbach's alpha score of 0.917 and IML-BBM score of 0.906 . Thus, two applications have a score of more than 0.900 so they fall into the category of "excellent", Reliability IML-WA percentage of $83.50 \%$ and IML-BBM of $82.66 \%$ are to be in the category of "very good".

Table 3. Independent test usability aspects

\begin{tabular}{|c|c|c|c|c|}
\hline \multicolumn{5}{|c|}{ Ranks } \\
\hline & Group & $\mathrm{N}$ & $\begin{array}{l}\text { Mean } \\
\text { rank }\end{array}$ & Sum of ranks \\
\hline Usability & $\begin{array}{l}\text { IML-WA } \\
\text { IML-BBM } \\
\text { Total }\end{array}$ & $\begin{array}{l}76 \\
76 \\
152\end{array}$ & $\begin{array}{l}79.90 \\
73.10\end{array}$ & $\begin{array}{l}6072.50 \\
5555.50\end{array}$ \\
\hline Test stat & tics & Usak & & \\
\hline Mann-Wh & ney U & 262 & & \\
\hline $\begin{array}{l}\text { Wilcoxon } \\
7\end{array}$ & & 555 & & \\
\hline $\begin{array}{l}\text { Z } \\
\text { Asymp. } \\
\text { tailed) }\end{array}$ & Sig. (2- & $\begin{array}{l}-.953 \\
.341\end{array}$ & & \\
\hline
\end{tabular}


As shown in Table 3, nonparametric independent test results on usability aspects, using a Mann-Whitney $U$ test, showed no significant differences between the two applications. However, the mean value showed that IML-WA was higher quality with a score of 79.90 compared to 73.10 for IML-BBM.

\subsection{Performance efficiency testing}

The performance efficiency results for the two applications are shown in Figures 2 and 3.

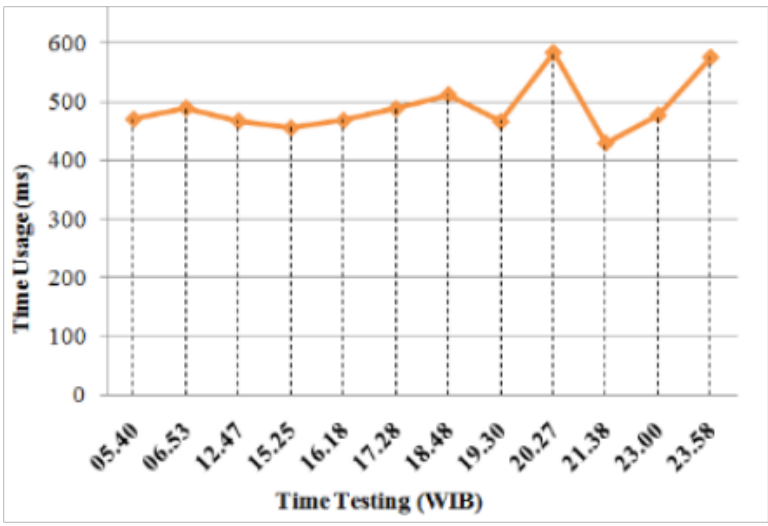

Figure 2. Performance efficiency aspects IML-WA

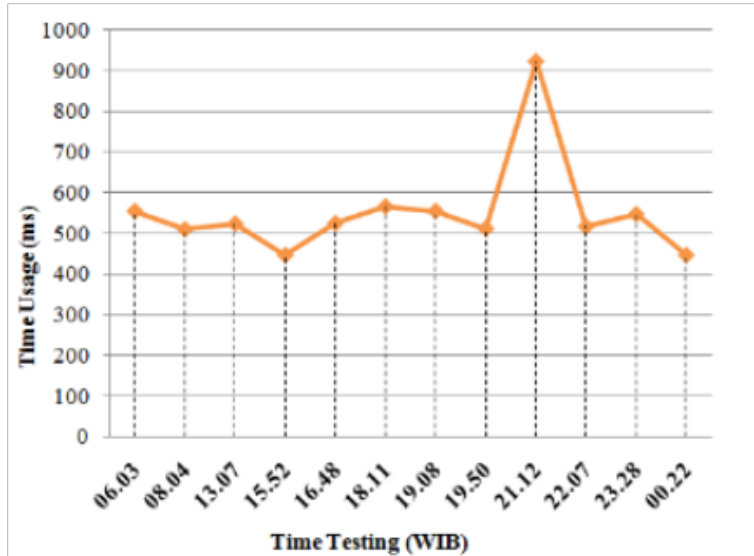

Figure 3. Performance efficiency aspects IML-BBM

The data from Figures 2 and 3 were used to test any significant difference between the two applications on time usage. The result of a Mann-Whitney $U$ test with SPSS is presented in Table 4.

Table 4. Performance efficiency aspects (time usage)

\begin{tabular}{lllll}
\hline \multicolumn{4}{c}{ Ranks } \\
\hline & Group & $\mathrm{N}$ & $\begin{array}{l}\text { Mean } \\
\text { rank }\end{array}$ & Sum of ranks \\
\hline Usability & IML-WA & 12 & 10.00 & 120.00 \\
& IML-BBM & 12 & 15.00 & 180.00 \\
& Total & 24 & & \\
\hline
\end{tabular}

Test statistics

Usability

Mann-Whitney U

42.000 


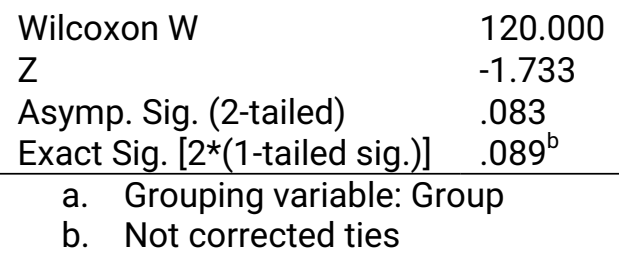

The performance efficiency testing shows: (1) the IML-WA application has an average score of 4.92 seconds and the IML-BBM application has an average score of 5.53 seconds, thus it shows that both applications have the predicate "satisfied", as presented by Hoxmeier (2000); (2) there was no significant difference in the time used on the two applications, but the mean rank shows that IML-WA takes less time, with a score of 10.00, meanwhile IML-BBM had the score 15.00 .

\section{CONCLUSIONS}

Based on the results of the research it can be concluded as follows:

1. Two learning media produce $100 \%$ functional suitability aspect quality, so the functions in the application work very well. The compatibility aspects can operate on more than 208 Android platform devices.

2. The level of user satisfaction based on usability aspect analysis shows that the IMLWA application is higher quality than IML-BBM.

3. The performance efficiency level of the two applications shows the IML-WA is higher quality than IML-BBM.

4. The results of the analysis and test differences indicate that the IML-WA application is higher quality and the best choice for the user.

\section{REFERENCES}

APJII. (2017). Hasil survey penetrasi dan perilaku pengguna internet Indonesia [Survey results on penetration and behavior of Indonesian internet user]. Retrieved from https://www.apjii.or.id

Baswedan, A. (2014). Surat menteri pendidikan dan kebudayaan [the letter of ministry of educational and cultural]. Retrieved from http://www.kemdiknas.go.id

Bitbar. (2018). Compatibility of online testing. Retrieved from www.cloud.bitbar.com

Branch, R.M. (2009). Instructional design: The ADDIE approach. New York, US: Springer.

Candradewi. (2018). Promoting education 4.0 in English for survival class: What are the challenges? Journal of English Language, Literature, and Teaching, METATHESIS, 2(1), 12.

David, A.B. (2011). Mobile application testing best practices to ensure quality - AMDOCS. Retrieved from http://www.globaltelecomsbusiness.com

George D. \& Mallery P. (2003). SPSS for Windows step by step: A simple reference 11.0 update (4th ed.). Boston: Allyn \& Bacon.

Google Play Store. (2018). Messenger application detail. Retrieved from https://play.google.com/store/apps/detail?id

Hidayati, A., Sarwosri, \& Ririd, A.R.T.H. (2009). Analisa pengembangan model kualitas berstruktur hirarki dengan kustomasi ISO 9126 untuk evaluasi aplikasi perangkat lunak B2B [Analysis of the development of a hierarchical structured quality model with ISO 9126 customization for B2B software application evaluation]. Presented in National Seminar of Electrical, Informatic, and It's Education (pp. 1-8). Malang, Indonesia: Teknik Elektro Universitas Negeri Malang.

Hoxmeier, J.A. \& Dicesare, C. (2000). System response Time and User Satisfaction: An Experimental Study of Browser Base Applications. AMCIS 2000 Proceedings (pp. 143). Retrieved from http://www.collector.org/achives/2000_april/03.pdf 
IDC Team. (2018). Smartphone market share. Retrieved from https://www.idc.com

ISO/IEC. (2011). Systems and software engineering - systems and software quality requirements and evaluation (SQuaRE). Retrieved from https://www.iso.org.

Juwarti. (2015). Pengembangan media animasi berbasis Android materi sistem saraf untuk meningkatkansikap ilmiah dan hasil belajar kognitif siswa SMAkelasXI. [Development of android-based animation media nervous system material to improve scientific attitudes and cognitive learning outcomes for grade XI high school students]. Unpublished thesis, Program Pascasarjana Universitas Negeri Yogyakarta, Indonesia.

Kobiton. (2018). Compatibility of online testing. Retrieved from www.portal.kobiton.com

Mili, A. \& Tchier, F. (2015). Software testing - concept and operations. USA: John Wiley \& Sons, Inc.

Nielsen, J. (2012). How many test user in a usability study? Retrieved from http://www.nngroup.com/articles/how-many-test-users/

Niknejad, A. (2011). A quality evaluation of an android smartphone application. Retrieved from https://gupea.ub.gu.se/bitstream/2077/26728/1/gupea_2077_26728_1.pdf

Panovski, G. (2008). Product software quality. Unpublished thesis, department of mathematics and computing science. TechnischeUniversiteit Eindhoven, Germany

Prasetyo, Y.D. (2015). Pengembangan Media Pembelajaran Kimia Berbasis Android padaMateriSistemKoloiduntukmeningkatkanMotivasiBelajardanHasilBelajarKognitifPesertaD idik SMA [Development of Android-based Chemistry Learning Media on Colloidal System Material to improve Learning Motivation and Cognitive Learning Outcomes of High School Students].Unpublished thesis, Program Pascasarjana Universitas Negeri Yogyakarta, Indonesia.

StatCounter. (2018). Mobile \& tablet android version market share worldwide. Retrieved from http://gs.statcounter.com.

Suman, M.W. (2014). A comparative study of software quality models. International Journal of Computer Science and Information Technologies (IJCSIT), 5(4), 5634.

Sumari, G.D. (2015). Pengembangan mobile learning berbasis Android materi sistem imun untuk meningkatkan kemampuan berpikir kritis dan kemandirian belajarsiswa kelas XI SMA [Developing Android Based Mobile Learning on Immune System to Improve the Critical Thinking and Learning Autonomy of Class XI Student of Senior High School]. Unpublished Thesis, Program Pascasarjana Universitas Negeri Yogyakarta, Indonesia.

Thomas, J.W. (2017). Product testing. Retrieved from https://decisionanalyst.com

UNESCO. (2014). Mobile learning. Retrieved from http://www.unesco.org

Vaugan, T. (2011). Multimedia: Making it Work. Eighth Edition. USA: McGraw-Hill

Wagner, S. (2013). Software product quality control. New York, NY: Springer.

Xing B. \& Marwala T. (2017). Implications of the fourth industrial age on higher education. Retrieved from https://www.researchgate.net 